\begin{tabular}{c} 
Volume and Issues Obtainable at Center for Sustainability Research and Consultancy \\
Journal of Business and Social Review in Emerging Economies \\
ISSN: 2519-089X (E): 2519-0326 \\
Volume 6: No. 3, 2020 \\
JSRᄃ \\
Journal homepage: www.publishing.globalcsrc.org/jbsee \\
\hline
\end{tabular}

\title{
Role of Advertising and Sales-Promotions to Create Brand-Satisfaction in the FMCG; Evidence from Pakistan
}

\author{
${ }^{1}$ Waheed Asghar, ${ }^{2}$ Rabia Rasheed, ${ }^{3}$ Aziz Khan Niazi \\ ${ }^{1}$ Director in Technical Education and Vocational Training Authority, (Government of the Punjab), Lahore, Pakistan, \\ waheedasgharpk@gamil.com; director.at@tevta.gop.pk \\ ${ }^{2}$ Assistant Professor, Department of Business Administration, Iqra University Karachi, Pakistan, \\ rabia.rasheed@iuk.edu.pk \\ ${ }^{3}$ Assistant Professor, Institute of Business and Management, University of Engineering \& Technology, Lahore, \\ Pakistan, azizniazi@uet.edu.pk
}

\begin{abstract}
ARTICLE DETAILS
History

Revised format: August 2020

Available Online: September

2020

\section{Keywords}

brand satisfaction, consumer loyalty, brand expectations, brand experience, brand quality, brand value, advertising, sales promotions, FMCG sector
\end{abstract}

\section{JEL Classification}

M40, M48

\section{ABSTRACT}

The role of brand satisfaction as a predecessor of brand loyalty has been acknowledged by researchers, academicians, and practitioners for long. Various concepts, theories, and models have been presented in the literature to understand the antecedents and predictors of brand satisfaction. It has been propounded that advertising supports to incite brand satisfaction. At the same time, many studies go against this point of view indicating its detrimental role in this regard. Although the research on sales promotions and brand satisfaction in the context of quality, performance, and value perceptions is meagre, it tends to depict it, for the most time, damaging and therefore unsuitable. This empirical research is an attempt to explore the comparative effectiveness of advertising and sales promotions to cause brand satisfaction bearing in mind all important constructs. The research has been conducted on the Fast Moving Consumer Goods sector. Two mostly purchased products consuming minimal household budget i.e. bath soap and toothpaste are selected for the purpose. The study findings, although determine advertising relatively more efficacious to produce feelings of satisfaction towards a brand, the role of sales promotions cannot be downplayed as they are equally important in respect of brand quality and utilitarian value.

\section{OPEN ACCESS}

(C) 2020 Center for Sustainability Research and Consultancy Pakistan under a Creative Commons Attribution-NonCommercial-ShareAlike 4.0

Corresponding author's email address: waheedasgharpk@gamil.com; director.at@ tevta.gop.pk

Recommended citation: Asghar, W., \& Niazi, A. K. (2020). Role of Advertising and Sales-Promotions to Create Brand-Satisfaction in the FMCG; Evidence from Pakistan. Journal of Business and Social Review in Emerging Economies, 6(3), 1118-1129

\section{Introduction}

\subsection{Brand Satisfaction}

Consumer satisfaction is an important concern of interest for researchers, academicians, and managers because it has a 
relationship not only with the performance of a company but also has implications for customer loyalty and brand equity (Bennett and Rundle-Thiele, 2004). It is often conceived that if a customer is satisfied, he is prone to display loyalty behaviour, i.e. repeated buying and disposition to pass on a positive word of mouth (Sondoh, Omar, Wahid, Ismail and Harun, 2007).

Brand satisfaction can be described as "outcome of the subjective evaluation that the chosen alternative (the brand) meets or exceeds the expectations" (Engel, Blackwell and Miniard, 1990, p. 481). Oliver (1997, p. 13) defined satisfaction as "the consumer's fulfilment response". The notion that stands out in almost every definition of satisfaction is that of comparison between expectations and experience i.e. brand performance (Bennett, Härtel, Charmine and McColl-Kennedy, 2005). In other words, there should be a strong positive relationship between consumer expectations and brand experience.

Interestingly, Olson \& Dover, (1979) maintained that customer expectations are the beliefs about a brand, that act like a reference point or a comparison standard against which product performance is evaluated. This expectation theory has wider implications. One of them is the expectancy disconfirmation, which suggests that the consumer feels gratified when the brand performs better than expected (positive disconfirmation). The other implication describes a dissatisfied customer when his/her expectations exceed actual product performance (negative disconfirmation). The last implication refers to the situation where the product performance is equal to the expectations (zero disconfirmation/confirmation) Consequently, as an experience characteristic, brand satisfaction will be determined by the consumer's evaluation of his indirect (advertising, word of mouth, brand reputation) and direct (e.g. trial or usage) exposure to the brand (Keller, 1993). Similarly, quality is an important element of satisfaction as indicated by Yi (1991) and Kotler (1991). The former offers an excellent appraisal of customer satisfaction and the main constructs identified during consumer research like discerned quality, expectations, and disconfirmation as discussed above.

Yet, another important element of satisfaction is the brand's perceived value. In their empirical study, Patterson and Spreng (1997) examine the correlation between four key post-purchase constructs: perceived performance, satisfaction, perceived value, and repurchase intentions, in a causal path framework. Their results show that the effect of perceived value on repurchase intentions is completely mediated through satisfaction.

In similar research, McDougall and Levesque (2000) investigated the relationship between three elements- quality, relational quality, and perceived value-customer satisfaction and future intentions in the services sector. Their results also revealed that core quality (the promise) and perceived value were the most important drivers of customer satisfaction. In short, product expectations, experience, quality, and perceived value are the most important elements of brand satisfaction.

The following figure depicts brand satisfaction constructs concerning sales promotions and advertising.

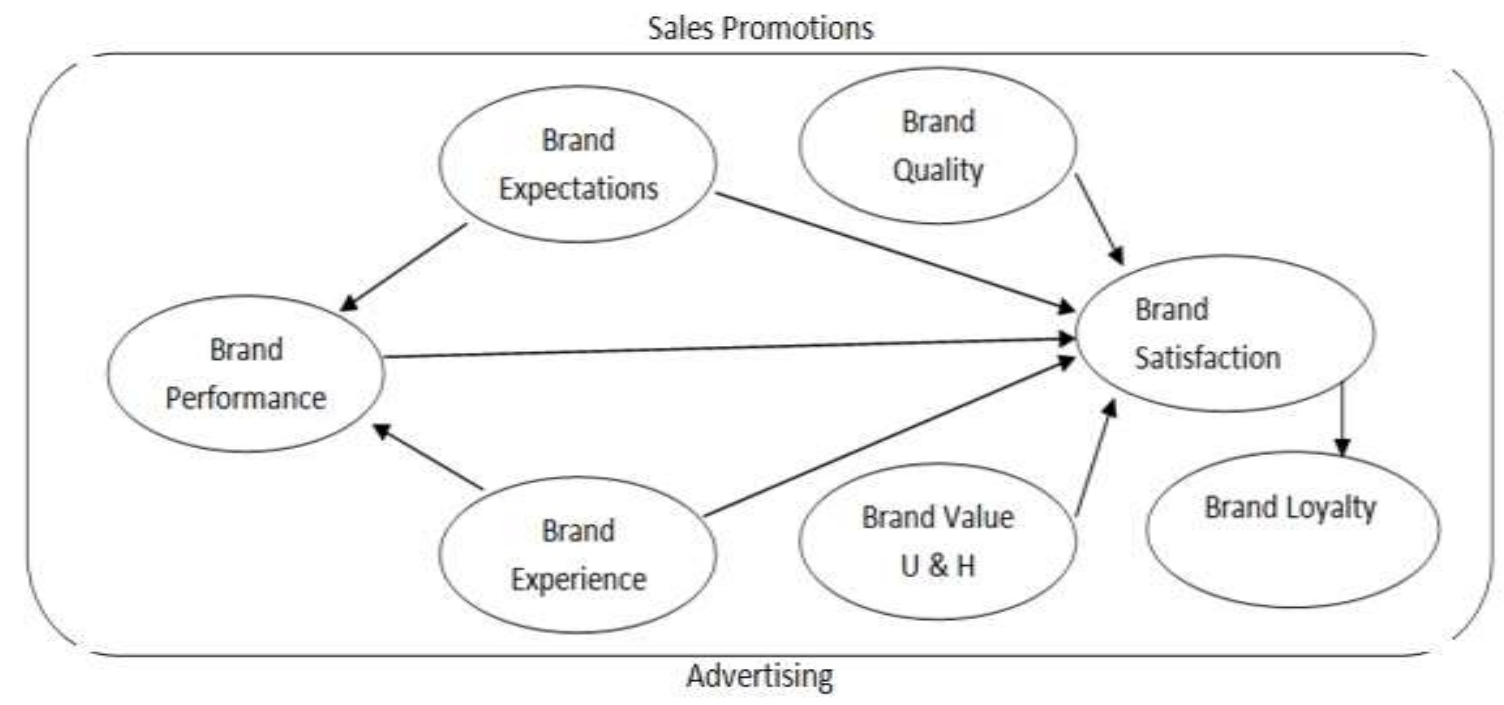


Figure 1: Brand Satisfaction Constructs

\subsection{Effects of Advertising and Sales Promotion on Brand Satisfaction}

It has been noticed that firms widely employ advertising and sales promotions as a direct persuasive communication tool in enticing and retaining customers (Yang, Bi, and Zhou, 2005). Belch and Belch, (2001) reported advertising as a versatile marketing tool that has long been used to attract customers, reinforce attitudes and loyalty, and increase sales and profits. Similarly, the role of sales promotion to attract, persuade and retain customers has been pointed out in literature (for example Mullin, and Cummins, 2008; Peattie and Peattie 1994). In one of the earliest researches, Bain (1956) advanced the argument that advertisement nurtures product differentiation perception amongst otherwise very alike brands. Bain writes, "product differentiation is propagated by [......] advertising and sales promotion efforts designed to win the allegiance and custom of the potential buyer." (p.114).

It is usually believed that advertising is helpful to cast a direct positive effect on forming expectations about a product or a brand, which can be best illustrated through the renowned theory of hierarch of effects (see, for example, Lavidge and Steiner, 1961; Aaker and Day, 1974; Aaker, Batra, and Myers, 1992). The most important role of advertising is the improvement of brand awareness and beliefs thereof (Deighton, Henderson and Neslin, 1994) and hence brand expectations: declaring about the presence or existence of the brand, and convincing and persuading the customers that the brand possesses various features and attributes (Dick and Basu, 1994). In case the efforts are successful, the consumers are more likely to buy the brand (Deighton, Henderson and Neslin, 1994). In short, advertising for these brands increases the knowledge of the customer about the brand, which triggers brand expectations by gaining the attention and processing of purchase decision information (Kent and Allen, 1994).

The present literature provides evidence about the negative impacts of advertising, the formation of consumer expectations, and satisfaction. Sometimes, advertising gives a glossy image of the brand leading consumers to form high expectations (Ehrenberg, 2000). But, when there is a deviation between this specious image and the actual brand performance, (i.e. between expectations and experience), the consumer may get disappointed (O'Loughlin and Szmigin, 2005). In cognitive dissonance and contrast theories, it has been propounded that consumers react differently to no-fulfilment of expectations generated through advertisement claims. Cognitive dissonance is an unpleasant state that arises when a person recognises the inconsistency of the experience and the beliefs (i.e. expectations), and it occurs when consumers feel that a product fails to meet the expectations generated by advertisement (Korgaonkar and Moschis, 1982). On the contrary, Thune, Bultiko, Spetch, and Webb (2010) maintain that to relieve themselves of this disagreement, consumers revise their assessment and try to reflect less negatively by matching their positive sentiments with the advertising message. On the other hand, unlike cognitive dissonance, contrast theory describes a phenomenon wherein the relationship between consumer expectation and product assessment is negative (Thune, et al., 2010). For example, Thune, et al., (2010) emphasize that when a product fails to meet consumer expectations - formed due to advertising messages - the higher the expectations the more negative its final assessment will be. Korgaonkar and Moschis' (1982) work suggests that contrast theory will be applicable in low involvement situations also.

Many a time, it has been proposed that price promotions do not induce repurchase behaviour for the brand (see, for example, Neslin and Shoemaker, 1989; Ehrenberg, Hammond, and Goodhardt, 1994). But some researchers have challenged this argument based on Skinner's (1938) behavioral learning theory, which posits that rewarded behavior is more likely to persist. Promotions can serve as a reward, thereby reinforcing subsequent purchase behavior (Rothschild and Gaidis, 1981). Furthermore, if a consumer purchases a brand due to promotion (that otherwise, he might not have purchased), and finds performing up to his expectation, it may enforce repurchase behavior (Peattie and Peattie, 1994). Wakefield and Barnes (1996) maintain that properly designed sales promotions may boost shortterm sales besides building customer loyalty. They argue that price promotions, particularly enhance the value of a brand. It has also been noted that promotions in FMCG induce variety-seeking behaviour (Kahn and Raju, 1991) as frequent promotions help consumers try different brands.

Sales promotions can help increase satisfaction in two ways. According to Chandon, Wansin, and Laurent (2000), sales promotions' value expression benefit is different and entails both utilitarian and hedonic attributes. They 
maintain that on one hand buying a promoted product can provide customers with an inner satisfaction of behaving in agreement with their principles and values e.g. being smart purchasers. It may be referred to as a hedonic or intrinsic benefit. At the same time, purchasing a product on promotion may become a source to increase customer's prestige and to achieve more prominent social status or affiliation with a group (e.g., to become a recognized as a thrifty shopper and a market connoisseur) — an extrinsic or utilitarian benefit.

As discussed earlier, satisfaction relates to brand evaluations as it is a result of brand performance or experience against the expectations. By cutting down the price of a brand or a product, or by extra smaller package or by offering a free sample, sales promotions can ease budget restrictions and allow the shopper to try a brand (Chandon, et al., 2000); and if the brand exceeds the expectations, it will result in satisfactions and will be included in the purchase set of customers (Taylor 1997; Bloomer and Kasper, 1995). Just like the cost-saving benefit, the quality benefit concentrates on increasing the value for money. It can, therefore, be linked to the 'excellence' type of customer values discussed by Holbrook (1994). This benefit is a critical component of the price discrimination theory of price promotions (Blattberg and Wisniewski, 1989).

In the above discussion, it can be noted that the existing literature separately takes up the issue of brand satisfaction concerning advertising and sales promotions. Even the literature that is available on advertising, sales promotion and brand satisfaction, is fraught with inconsistent and confounding arguments and findings. These inconsistent findings necessitate conducting empirical research to find out the extent advertising or sales promotions can impact brand satisfaction, which ultimately results in consumer loyalty. The following hypotheses are thus developed to test the relationship between advertising, sales promotion and brand satisfaction.

H1: There is no difference between the effectiveness of Sales Promotions and Advertising to induce favorable expectations of a brand.

H2: There is no difference between the effectiveness of Sales Promotions and Advertising to induce better feelings about a positive experience with the brand.

H3: There is no difference between the effectiveness of Sales Promotions and Advertising to impart signals of superior quality of a brand.

H4: There is no difference between the effectiveness of Sales Promotions and Advertising to strengthen the belief of deriving utilitarian value from a brand.

H5: There is no difference between the effectiveness of Sales Promotions and Advertising to strengthen the belief of deriving hedonic value from a brand.

H6: There is no difference between the effectiveness of Sales Promotions and Advertising to induce the feeling of satisfaction for a brand.

\section{Methodology}

\subsection{Why Fast Moving Consumer Goods (FMCG) Sector?}

Although a few comparative research studies have been conducted about advertising and sales promotion in the past, comprehensive research involving various psychological and economic aspects of consumer the behaviour in the Fast Moving Consumer Goods sector has not been conducted. FMCG is the only sector where the consumer spends most of the budget and has to visit the store time and again. Most of the decisions regarding the purchase of FMCG are on the spot, making advertising and sales promotions the most effective tool of communication to ameliorate consumer behaviour. Then, the major part of the budget in FMCG is now diverted towards consumer sales promotions instead of advertising. According to Gomez, Rao and McLaughlin, (2007), about 70 to 75 percent of the marketing budget of consumer goods manufacturers is consumed in consumer promotions.

Toothpaste and bath soap were selected among product categories of the FMCG because these are most frequently purchased as being an essential part of the household budget (Horton, 1979). Secondly, there is stringent competition in these categories due to the proliferation of brands (Macrae and Uncles, 1997). Thirdly, not much household budget is spent on these categories, even in a country like Pakistan where a large majority of the population is underprivileged.

\subsection{Measures for Brand Satisfaction}


This study entailed the use of expectation, experience, quality and value elements to appraise satisfaction. Expectation was measured using two items on a 7-point bipolar scale. The respondents were asked what you expect of the brand with endpoints 'inferior -superior' (see: Dolich, 1969) and what you feel about the brand with endpoints "very undesirable - very desirable" (see: Adaval, 2001; Yoo and Donthu, 2001). Similarly, respondents were asked about their experience with the brand on two-item, 7-point scales. They were asked to rate their overall experience with the brand as "very dissatisfied - very satisfied" (Spreng, MacKenzie and Olshavsky, 1996; Li, 2006) and their fulfilment of the expectations as "fulfilled - disappointed." These measures were used by Cadotte, Woodruff and Jenkins, (1987). Quality was evaluated on Buchanan, Simmons and Bickart's (1999) scale labelling "exceptional - ordinary" and Low and Lamb's (2000) 7-point scale labelling "low quality - high quality." Alpha reliability of the scale with the actual sample remained within the acceptable standards i.e. Cronbach alpha for all the above scales was above .81.

The utilitarian value element of brand satisfaction was measured using the scale of Sweene and Soutar (2001) and Lassar, Mittal and Sharma (1995). Two-item, seven-point Likert Scale was used with the statements 'do you consider the brand good product for money due to $\mathrm{ad} / \mathrm{SP}$ ' and 'does the brand offer value for money due to ad/SP'. The hedonic value was measured using Chaudhuri and Holbrook's (2001) Likert scale with the statements 'Due to ad/SP, I feel good when I use this brand' and 'I love this brand due to ad/SP. Cronbach's alpha for utilitarian and hedonic measures was .75 and .95 respectively.

\subsection{Data Collection}

Mall intercept - a data collection technique - was used to collect data due to two reasons. Firstly, the study subjects were located conveniently and secondly, it was considered more appropriate to obtain instant feedback from shoppers coming right away out of a grocery store and having fresh and firsthand shopping experience. It was targeted to get a response from eight hundred customers and to request them to participate in the study. Nevertheless, 428 cooperated and agreed to fill the questionnaire. Out of 428, 243 were male respondents and 185 were females. It was deliberated effort that the respondents are only those persons who actively participate in the family's decision-making process and have the key position in this regard. Demographic diversity was also ensured as the data was collected from eight metropolitan cities in Pakistan.

\section{Data Analysis}

\subsection{Validity and Reliability}

No statistical procedure was required to find out content and face validity as the measures were derived from the existing literature (Rundle-Thiele, 2005; Bohrnstedt, 1983). Nevertheless, the face validity was ensured through expert review of the measures and instrument, and pilot test of the questionnaire respectively. The reliability statistics, the value of Cronbach's coefficient $\alpha$, for satisfaction constructs and measures was .810 which has been described acceptable for social sciences studies (Cortina, 1993). For all other constructs, the coefficient alpha value is also greater than .7 except brand value which is almost .7 (i.e. .697).

Table 2: Reliability Statistics for Brand Satisfaction and its Constructs

$\begin{array}{ccc}\text { Variable } & \text { Cronbach's alpha } & \text { No. of Items } \\ \text { Brand Expectation } & .732 & \mathbf{4} \\ \text { Brand Experience } & \mathbf{7 0 8} & \mathbf{4} \\ \text { Brand Quality } & \mathbf{7 8 7} & \mathbf{4} \\ \text { Brand Value (U\&H) } & \mathbf{. 6 9 7} & \mathbf{8} \\ \text { Satisfaction (Overall) } & \mathbf{8 1 0} & \mathbf{2 0}\end{array}$




\subsection{Factor Analysis}

KMO value was .878 and Bartlett's Test of Sphericity was significant at $p=0.000$ (see Table 3 ). These values showed a significant correlation among the variables (Hair, Anderson, Tatham, and Black, 1998) demonstrating the suitability of data for factor analysis.

Table 3: Statistics Showing Suitability of Data for Factor Analysis

KMO and Bartlett's Test

\begin{tabular}{l|cc}
\hline \multicolumn{2}{c}{ Kaiser-Meyer-Olkin Measure of Sampling Adequacy. } & .878 \\
\hline Bartlett's Test of Sphericity & Approx. Chi-Square & $3.267 \mathrm{E} 3$ \\
& $\mathrm{df}$ & 190 \\
& Sig. & .000 \\
\hline
\end{tabular}

The Kaiser's criterion to extract factors using Principal Component Analysis exhibited four components having Eigenvalue greater than 1 . These four components explained a total variance of 54 percent as shown in Table 4 .

Table 4: Total Variance Explained

Total Variance Explained

\begin{tabular}{|c|c|c|c|c|c|c|c|c|c|}
\hline \multirow[t]{2}{*}{ Component } & \multicolumn{3}{|c|}{ Initial Eigenvalues } & \multicolumn{3}{|c|}{$\begin{array}{c}\text { Extraction Sums of Squared } \\
\text { Loadings } \\
\end{array}$} & \multicolumn{3}{|c|}{$\begin{array}{c}\text { Rotation Sums of Squared } \\
\text { Loadings } \\
\end{array}$} \\
\hline & Total & $\begin{array}{c}\% \text { of } \\
\text { Variance } \\
\end{array}$ & $\begin{array}{c}\text { Cumulative } \\
\% \\
\end{array}$ & Total & $\begin{array}{c}\% \text { of } \\
\text { Variance }\end{array}$ & $\begin{array}{c}\text { Cumulative } \\
\% \\
\end{array}$ & Total & $\begin{array}{c}\% \text { of } \\
\text { Variance }\end{array}$ & $\begin{array}{c}\text { Cumulative } \\
\% \\
\end{array}$ \\
\hline 1 & 6.704 & 33.522 & 33.522 & 6.704 & 33.522 & 33.522 & 3.274 & 16.368 & 16.368 \\
\hline 2 & 1.946 & 9.731 & 43.253 & 1.946 & 9.731 & 43.253 & 3.147 & 15.737 & 32.105 \\
\hline 3 & 1.287 & 6.435 & 49.688 & 1.287 & 6.435 & 49.688 & 2.553 & 12.763 & 44.868 \\
\hline 4 & 1.018 & 5.090 & 54.778 & 1.018 & 5.090 & 54.778 & 1.982 & 9.910 & 54.778 \\
\hline 5 & .943 & 4.716 & 59.494 & & & & & & \\
\hline 6 & .911 & 4.553 & 64.047 & & & & & & \\
\hline . & & . & . & & & & & & \\
\hline . & & & $\cdot$ & & & & & & \\
\hline 20 & .204 & 1.020 & 100.000 & & & & & & \\
\hline
\end{tabular}

In order to get more interpretable results, Varimax rotation was applied and factor loadings below .5 were suppressed as practiced by many researchers like Meddis (1972), Mor-Barak (1995), King (1998), Freestone and Mitchell (2004), Lee, Back and Kim (2009).

The first component extracted was that of sales promotions and brand value (both utilitarian and hedonic). The second component was advertising and brand performance in terms of brand expectations and brand experience. The third component was sales promotion, brand expectation, brand experience (brand performance) and quality. The fourth component was advertising and hedonic brand value. It can be interpreted that advertising is not as effective for utilitarian brand value and brand quality as for other variables. The four components along with their factor loadings are depicted in Table 5.

Table 5: Rotated Component Matrix Showing 4 Components 


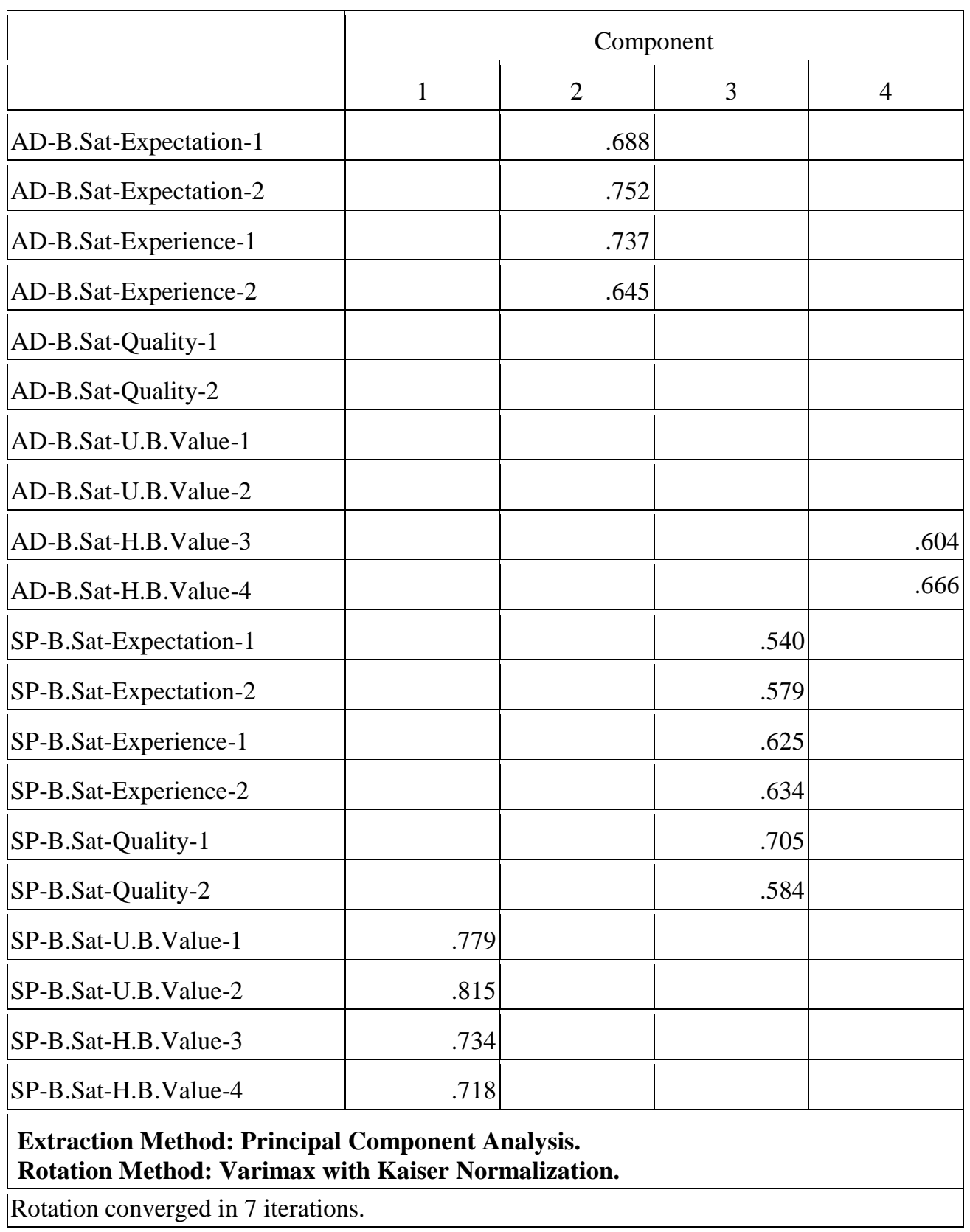

\subsection{Test of Hypotheses: Paired Sample t-test}

Hypotheses of the study were tested using paired sample t-test, which is a common technique to examine and note the similarities or differences of how a group of respondents performs in two distinctly separate conditions (Tang, Owen, Biocca and Mou, 2003), i.e. when the independent variable has two levels (Yamagishi, 1997). Furthermore, the paired t-test was found suitable for this research as the ordinal scale was used to collect the data. It was also in agreement with the Central Noraml Theorem stipulation as the size of the sample was greater than 30 for all the variables. Table 6 summarizes paired sample t-test results for the hypotheses of the study.

Table 6: Paired Sample t-test Statistics for Test of Hypotheses

Sub-Variablel

Paired Sample Statistics

Paired Sample Test

Variable

\begin{tabular}{llllllc}
\hline Sales Promotion & \multicolumn{2}{c}{ Advertising } & \multicolumn{3}{c}{$\begin{array}{c}\text { Sales Promotion - } \\
\text { Advertising }\end{array}$} \\
\hline Mean & $\begin{array}{l}\text { Standard } \\
\text { Deviation }\end{array}$ & Mean & $\begin{array}{l}\text { Standard } \\
\text { Deviation }\end{array}$ & $t$ & df. & $\begin{array}{c}\text { Sig (2- } \\
\text { tailed) }\end{array}$ \\
\hline 10.28 & 2.54 & 11.21 & 2.312 & 7.071 & 427 & .000
\end{tabular}




\begin{tabular}{|c|c|c|c|c|c|c|c|}
\hline $\begin{array}{l}\text { H2: Brand } \\
\text { Experience }\end{array}$ & 10.11 & 2.59 & 10.67 & 2.416 & 4.166 & 427 & .000 \\
\hline $\begin{array}{l}\text { H3: Brand } \\
\text { Quality }\end{array}$ & 10.31 & 4.35 & 10.72 & 2.31 & 1.681 & 427 & .063 \\
\hline $\begin{array}{l}\text { H4: Utilitarian } \\
\text { Brand Value }\end{array}$ & 9.94 & 2.84 & 10.18 & 5.04 & .963 & 427 & .336 \\
\hline $\begin{array}{l}\text { H5: Hedonic } \\
\text { Brand Value }\end{array}$ & 9.79 & 2.79 & 10.52 & 4.83 & 3.163 & 427 & .000 \\
\hline H6: Brand & 50.46 & 11.43 & 53.32 & 11.10 & 5.386 & 427 & .000 \\
\hline
\end{tabular}

\section{Results and Conclusion}

The results in Table 6 demonstrate that H1, H2, H5, and H6 are rejected since the probability of getting the observed sample results if the null hypothesis is true is .000 . However, based upon the mean differences for each of these hypotheses it can be deduced that advertising is relatively a better tool to prompt favourable expectations and better feelings about a positive experience. Again, advertising has an edge over sales promotion to strengthening the belief of deriving hedonic value and to induce the overall feeling of satisfaction for a brand. In so far as H4 and H5 are concerned, there is weak evidence in favour of the alternative hypothesis implying that the null hypothesis cannot be rejected. So, sales promotions and advertising can be effective to impart signals of superior quality of a brand and to build up the belief of deriving hedonic value from a brand. The mean difference between these two hypotheses, however, shows that sales promotions are superior to the advertisement in both cases.

\section{Analysis of the Findings}

The analysis of data demonstrates that there were factor loadings for advertising concerning brand expectations and brand experience. It can be inferred that brand performance perception is relatively improved by advertising. Advertising also appears to be important for hedonic brand values. Sales promotions received factor loadings for brand quality and utilitarian brand value also, whereas there was none for these constructs regarding advertising.

The mean difference in paired sample t-test for brand satisfaction constructs demonstrated that advertising is relatively superior to sales promotions regarding brand performance measures of expectation and experience. For both these constructs, the mean difference is -.92757 and -.55841 respectively. In so far as brand quality and utilitarian brand value are concerned, advertising and sales promotions were found to be equally important as null hypotheses could not be rejected. However, advertising is again found relatively better regarding hedonic brand value. When paired ttest was employed to overall satisfaction variable, advertising established an edge over sales promotion as the null hypothesis of equal influence was rejected. Similarly, the mean difference for overall satisfaction noted a reasonable divergence, which is -2.85981 . Figure 3 depicts the findings of the study denoting better toll (advertising and sales promotions) with " $>$ "

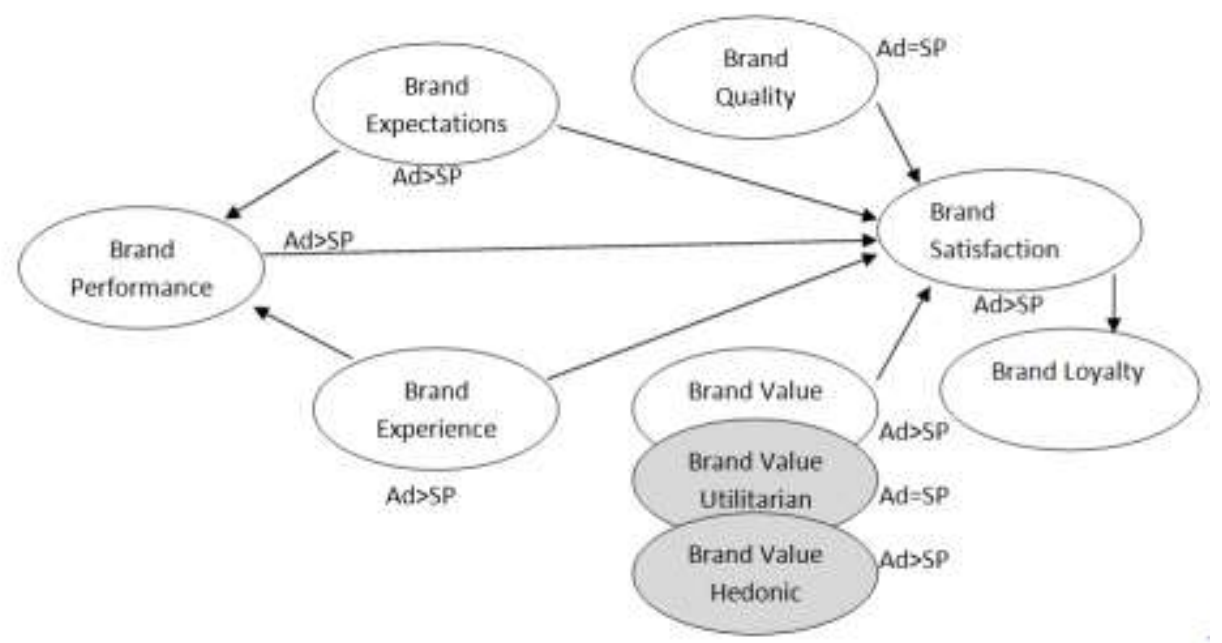

Figure 2: Results of the Study 


\section{Managerial Implications}

All these findings provide practical guidelines to marketing practitioners. The previous research has emphasized the use of advertising to build brand loyalty (for example Aaker et al., 1992; Jensen and Hansen, 2006) of which satisfaction is the most important variable. It is required by a brand manager that the consumer feels satisfied with the brand after its purchase. Positive cues about the brand can be communicated to the customers through advertising. However, these cues must not be overstated as expectations about a brand are formed due to the former (Semenik, Zhou and Moore, 1986). If there will be a fit between customer expectations of a brand and the experience with the brand, the result will be the satisfaction with the brand (Biedenbach and Marell, 2009). Similarly, extrinsic brand quality cues may be passed on to the customer through advertising, increasing satisfaction level (Yoo, Donthu and Lee, 2000). Although sales promotions may be accommodating to induce a trial of a brand for experiencing quality, advertising is equally important in the empirical findings of this study. Advertising provides a large amount of information to customers, which helps them to arrive at a decision and to make an appropriate choice (Hyun, Kim and Lee, 2011). Hyun et al. (2011) further maintained that advertising induces emotional responses that positively influence the perceived quality of a product. Moorthy and Hawkins (2005) also posited that advertising works as an indicator of a brand quality coz consumers perceive that high-quality brands would advertise more frequently than low-quality brands. They supported advertising repetitions as it influences perceived quality. Thomas, Shane and Weigelt (1998) also postulate that advertising helps to impart quality signalling. It is due to these reasons that marketing practitioners use both price and advertising to signal the quality of their products.

As found in this study, sales promotions are equally important to impart positive signals about brand quality. This finding is quite contrary to that of Yoo, et al. (2000) and Grewal, Krishnan, Baker and Borin (1998) who argue that sales promotions may convey a low-quality brand image. In short, both advertising and sales promotions can help to establish brand satisfaction and ultimately brand loyalty. A brand manager should sagaciously use both the tools to enhance market share and to keep the customers loyal for a long term period.

It would be rational to conclude that advertising is relatively better to stimulate the feeling of satisfaction. However, the role of Sales Promotions cannot be undermined. There will be a synergetic effect if sales promotions and advertising are allowed to play their respective roles as empirically found in this study.

\section{Limitations and Future Research}

As the research has been conducted on the FMCG sector in Pakistan, the results may not apply to other countries, especially advanced ones, because sales promotion offers in FMCG are more frequent there. Moreover, this study was on two product categories in the low involvement product category i.e. toothpaste and bath soap. Furthermore, some more categories can be included in obtaining a real insight into the sector. Then, only two sorts of price promotions were used for the study i.e. discounts and buy-one-get-one-free, which do not correspond to the whole of sales promotions. It is also suggested that there should be a study which involves other monetary and non-monetary promotions like lucky draws, prizes, bonus/ extra product etc. Comparing advertising with these types of incentives may yield different results. Last but not the least, as customers are less loyal to FMCG products, research on durable and luxury products may lead to yield interesting findings.

\section{References}

Aaker, D. A., and Day, G. S. (1974), “A dynamic model of relationships among advertising, consumer awareness, attitudes, and behaviour", Journal of Applied Psychology, Vol. 59 No. 3, p. 281.

Aaker, D. A., Bart, R., and Myers, J. (1992), Advertising Management, Prentice Hall, Englewood Cliffs, New Jersey.

Adaval, R. (2001), "Sometimes It Just Feels Right: The Differential Weighting of Affect-Consistent and AffectInconsistent Product Information", Journal of consumer research, Vol. 28 No. 1, pp. 1-17.

Bain, J. S. (1956), Barriers to New Competition, Cambridge, MA, Howard University Press.

Belch, G., and Belch, M., (2001), Introduction to Advertising and Promotion: An Integrated Marketing Communications Perspective, McGraw Hill, New York.

Bennett, R., and Rundle-Thiele, S. (2004), "Customer satisfaction should not be the only goal", Journal of Services Marketing, Vol. 18 No. 7, pp. 514-523. 
Bennett, R., Hartel, C. E., and McColl-Kennedy, J. R. (2005), "Experience as a moderator of involvement and satisfaction on brand loyalty in a business-to-business setting 02-314R", Industrial Marketing Management, Vol. 34 No. 1, pp. 97-107.

Biedenbach, G., and Marell, A. (2009), "The impact of customer experience on brand equity in a business-to-business services setting", Journal of Brand Management, Vol. 17 No.6, pp. 446-458.

Blattberg, R. C., and Wisniewski, K. J. (1989), "Price-induced patterns of competition", Marketing Science, Vol. 8 No. 4, pp. 291-309.

Bloemer, J. M. M., and Kasper, H. D. (1995), "The complex relationship between consumer satisfaction and brand loyalty" Journal of economic psychology, Vol. 16 No.2, pp. 311-329.

Bohrnstedt, G., (1983), "Measurement", in Rossi P., Wright J. and Anderson A. (Ed.), A Hand Book of Survey Research, Academy Press, San Diego, CA.

Buchanan, L., Simmons, C. J., and Bickart, B. A. (1999), "Brand equity dilution: retailer display and context brand effects", Journal of Marketing Research, Vol. 36 No. 3, pp. 345-355.

Cadotte, E. R., Woodruff, R. B. and Jenkins, R. L. (1987), "Expectations and Norms in Models of Consumer Satisfaction", Journal of Marketing Research, Vol. 24 No. 3, pp. 305-314.

Chandon, P., Wansink, B., and Laurent, G. (2000), "A benefit congruency framework of sales promotion effectiveness", The Journal of Marketing, Vol. 64 No. 4, pp. 65-81.

Chaudhuri, A., and Holbrook, M. B. (2001), "The chain of effects from brand trust and brand affect to brand performance: the role of brand loyalty", The Journal of Marketing, Vol. 65 No. 2, pp. 81-93.

Cortina, J. M. (1993), "What is coefficient alpha? An examination of theory and applications", Journal of Applied Psychology, Vol. 78 No.1, p. 98.

Deighton, J., Henderson, C. M., and Neslin, S. A. (1994), "The effects of advertising on brand switching and repeat purchasing", Journal of Marketing Research, Vol. 31, pp 28-43.

Dick, A. S., and Basu, K. (1994), "Customer loyalty: toward an integrated conceptual framework", Journal of the Academy of Marketing Science, Vol. 22 No. 2, pp. 99-113.

Dolich, I. J. (1969), "Congruence relationships between self images and product brands", Journal of Marketing Research, Vol. 6, pp. 80-84.

Ehrenberg, A. S. (2000), "Repetitive advertising and the consumer", Journal of Advertising Research, Vol. 40 No. 6 , pp. 39-48.

Ehrenberg, A. S., Hammond, K., and Goodhardt, G. J. (1994), "The after-effects of price-related consumer promotions", Journal of advertising research, Vol. 34 No. 4, pp.11-21.

Engel, J.F., Blackwell, R.D. and Miniard, P.W. (1990). Consumer Behavior. (6th ed.), The Dryden Press, Chicago, IL.

Freestone, O., and Mitchell, V. (2004), "Generation Y attitudes towards e-ethics and internet-related misbehaviours", Journal of Business Ethics, Vol.54 No. 2, pp. 121-128.

Gomez, M. I., Rao, V. R., and McLaughlin, E. W. (2007), "Empirical analysis of budget and allocation of trade promotions in the US supermarket industry", Journal of Marketing Research, Vol. 44 No. 3, pp. 410-424.

Grewal, D., Krishnan, R., Baker, J., and Borin, N. (1998), "The effect of store name, brand name and price discounts on consumers' evaluations and purchase intentions", Journal of retailing, Vol.74 No.3, pp. 331-352.

Hair, J. F., Anderson, R. E., Tatham, R. L., and Black W. C. (1998), Multivariate data analysis, Prentice Hall, Upper Saddle River, NJ.

Holbrook, M.B. (1994), "The Nature of Customer Value: An Axiology of Services in the Consumption Experience", in Roland T. Rust and Richard L. Oliver (eds) Service Quality: New Directions in Theory and Practice, pp. 21-71. Thousand Oaks, SAGE, CA.

Horton, R. L. (1979), "Some relationships between personality and consumer decision making”, Journal of Marketing Research, Vol. 16, pp. 233-246.

Hyun, S. S., Kim, W., and Lee, M. J. (2011), “The impact of advertising on patrons' emotional responses, perceived value, and behavioral intentions in the chain restaurant industry: The moderating role of advertising-induced arousal" International Journal of Hospitality Management, Vol. 30, No. 3, pp. 689-700.

Jensen, J. M. 1., and Hansen, T. (2006), "An empirical examination of brand loyalty", Journal of Product \& Brand Management, Vol. 15 No. 7, pp. 442-449.

Kahn, B. E., and Raju, J. S. (1991), "Effects of price promotions on variety-seeking and reinforcement behaviour" Marketing Science, Vol. 10 No. 4, pp. 316-337. 
Keller, K. L. (1993), “Conceptualizing, measuring, and managing customer-based brand equity”, The Journal of Marketing, Vol. 57, pp. 1-22.

Kent, R. J., and Allen, C. T. (1994), "Competitive interference effects in consumer memory for advertising: the role of brand familiarity” The Journal of Marketing, Vol. 58 No 3, pp. 97-105.

Korgaonkar, P. K., and Moschis, G. P. (1982), “An experimental study of cognitive dissonance, product involvement, expectations, performance and consumer judgement of product performance”, Journal of Advertising, Vol. 11 No.3, pp. 32-44.

Kotler, P. (1991), Marketing Management, Prentice-Hall, Hemel Hempstead.

Lassar, W., Mittal, B., and Sharma, A. (1995), "Measuring customer-based brand equity", Journal of consumer marketing, Vol. 12 No. 4, 11-19.

Lavidge, R. J., and Steiner, G. A. (1961), "A model for predictive measurements of advertising effectiveness" The Journal of Marketing, Vol. 25 No. 3, pp. 59-62.

Lee, Y., Back, K., and Kim, J. (2009), "Family Restaurant Brand Personality and Its Impact on Customer's Emotion, Satisfaction, and Brand Loyalty", Journal of Hospitality and Tourism Research, Vol. 33 No. 3, pp. 305-28.

Macrae, C., and Uncles, M. D. (1997), "Rethinking brand management: the role of "brand chartering", Journal of Product \& Brand Management, Vol. 6 No. 1, pp. 64-77.

McDougall, G. H., and Levesque, T. (2000), "Customer satisfaction with services: putting perceived value into the equation", Journal of Services Marketing, Vol. 14 No. 5, 392-410.

Meddis, R. A. Y. (1972), "Bipolar Factors in Mood Adjective Checklists", British Journal of Social and Clinical Psychology, Vol. 11 No. 2, pp. 178-84.

Moorthy, S., and Hawkins, S. A. (2005), "Advertising repetition and quality perception" Journal of business research", Vol. 58 No. 3, pp. 354-360.

Mullin R., and Cummins J. (2008), Sales Promotions; how to create, implement and integrate campaigns that really work, 4th edition, Kogan Page Ldt, GB.

Neslin, S. A. and Shoemaker, R. W. (1989), “An alternative explanation for lower repeat rates after promotion purchases", Journal of Marketing Research, Vol. 25, May, pp. 205-13.

Oliver, R. L. (1997), "Satisfaction: A Behavioral Perspective on the Consumer", The McGraw-Hill Companies, Inc. New York.

O'Loughlin, D. and Szmigin, I. (2005), "Customer perspectives on the role and importance of branding in Irish retail financial services", International Journal of Bank Marketing, Vol. 23 No. 1, pp. 8-27.

Olson, J. C., and Dover, P. A. (1979), "Disconfirmation of consumer expectations through product trial", Journal of Applied Psychology, Vol. 64 No. 2, pp. 179-189.

Patterson, P. G., and Spreng, R. A. (1997), "Modelling the relationship between perceived value, satisfaction and repurchase intentions in a business-to-business, services context: an empirical examination" International Journal of Service Industry Management, Vol. 8 No. 5, pp. 414-434.

Peattie, S. and Peattie, K. J. (1994), Sales promotion, in Baker, M.J. (Eds) The Marketing Book. 3rd edition. Butterworth Heinemann, London.

Rothschild, M. L. and Gaidis, W. C. (1981), "Behavioral learning theory; its relevance to marketing and promotions" Journal of Marketing, Vol. 45, pp. 70-78.

Rundle-Thiele, S. (2005), "Exploring loyal qualities: assessing survey-based loyalty measures”, Journal of Services Marketing, Vol.19 No. 7, pp. 492-500.

Semenik, R. J., Zhou, N., and Moore, W. L. (1986), "Chinese managers' attitudes toward advertising in China" Journal of Advertising, Vol. 15 No. 4, pp. 56-62.

Skinner, B. F. (1938), The Behavior of Organisms: An Experimental Analysis, Appleton-Century Crofts, New York.

Sondoh Jr, S. L., Omar, M. W., Wahid, N. A., Ismail, I., and Harun, A. (2007), "The effect of brand image on overall satisfaction and loyalty intention in the context of color cosmetic", Asian Academy of Management Journal, Vol. 12 No. 1, pp. 83-107.

Spreng, R. A., MacKenzie, S. B., and Olshavsky, R. W. (1996), “A reexamination of the determinants of consumer satisfaction" The Journal of Marketing, Vol. 60 No. 3, pp. 15-32.

Sweeney, J. C., and Soutar, G. N. (2001), "Consumer perceived value: the development of a multiple item scale", Journal of retailing, Vol. 77 No. 2, pp. 203-220.

Tang, A., Owen, C., Biocca, F., and Mou, W. (2003), "Comparative effectiveness of augmented reality in object 
assembly" Paper presented at the Proceedings of the SIGCHI conference on Human factors in computing systems.

Taylor, K. (1997), “A regret theory approach to assessing consumer satisfaction” Marketing Letters, Vol. 8 No. 2 , pp. 229-38.

Thomas, L., Shane, S., \& Weigelt, K. (1998), “An empirical examination of advertising as a signal of product quality", Journal of Economic Behavior \& Organization, Vol. 37 No. 4, pp. 415-430.

Thune, D., Bultiko, V., Spetch, M., and Webb, M. (2010), "Exaggerated Claims for Interactive Stories" in Iurgel, I.A., Zagalo N. and Petta, P. (Ed), 2nd Joint International Conference on Interactive Digital Story Telling ICIDS 2009, Proceedings, Springer-Verlag Berlin Heidelberg.

Yamagishi, K. (1997), "When a 12.86\% mortality is more dangerous than 24.14\%: implications for risk communication", Applied Cognitive Psychology, Vol. 11 No. 6, pp. 495-506.

Yang, Z., Bi, Z., \& Zhou, N. (2005), "The double jeopardy phenomenon and the mediating effect of brand penetration between advertising and brand loyalty", Journal of Advertising Research", Vol. 45 No. 2, pp. 211.

Yi, Y. (1991), “A critical review of consumer satisfaction”, in Zeithaml, V.A. (ed.), Review of Marketing 1990, Chicago, American Marketing Association, pp. 68-123.

Yoo, B., and Donthu, N. (2001), "Developing and validating multidimensional consumer-based brand equity scale", Journal of business research, Vol. 52 No. 1, pp. 1-14.

Yoo, B., Donthu, N., and Lee, S. (2000), “An examination of selected marketing mix elements and brand equity”, Journal of the Academy of Marketing Science, Vol. 28 No. 2, 195-211. 